Vol. 6 (1997): 183-191.

\title{
Effects of cage size and obstructed view from cage on use of resting platforms by farmed silver foxes
}

\author{
Jaakko Mononen, Mikko Harri and Leena Ahola \\ University of Kuopio, Department of Applied Zoology and Veterinary Medicine, PO Box 1627, \\ FIN-70211 Kuopio, Finland, email: mononen@uku.fi
}

\begin{abstract}
The effects of cage size and an obstructed view from the cage on the use of wooden nonwalled resting platforms by juvenile male $(\mathrm{n}=10)$ and female $(\mathrm{n}=15)$ silver foxes (Vulpes vulpes) were assessed in a 10 week experiment. The degree of the view and the free floor area of the cage varied between the five types of cage used. Each animal spent 2 weeks in each type of cage and their behaviour was videorecorded for a $24-\mathrm{h}$ period in each 2 -week period. The foxes spent $59 \pm 13 \%$ of their daily time on the platforms. Use declined from $72 \pm 13 \%$ in September to $35 \pm 21 \%$ in November. Males used the platforms more than did females. In late October and early November, the foxes in cages with an obstructed view from the floor made more use of the platforms for both active behaviour and resting than did those in cages with an unobstructed view from the floor. The larger the free floor area of the cage, the less the silver foxes used the platforms during activity in mid-August and mid-September. One probable function of the platform is to offer the foxes an observation and resting place with an open view in all directions.
\end{abstract}

Key words: fur farming, animal behaviour, preference, animal welfare, housing

\section{Introduction}

According to the European Convention (1991), not all biological needs of farmed silver foxes (Vulpes vulpes) and blue foxes (Alopex lagopus) are met in the current commercial husbandry systems. As a minimum requirement, the Convention recommends that a suitable nest box or platform should be available for each fox. If a platform only is available, it should have solid sides. These structures should be placed as high as possible. The Convention lists the needs as a solid floored resting site, an observation place, a hiding place, and the possibility to stay on a higher level than the cage floor. Of these four needs, only the latter is systematically supported by the results of previous platform studies on silver foxes (see a review by Mononen et al. 1996c). It may be connected with the need of an animal for an observation place providing an unobstructed view. Height and/or unobstructed view may be key features of the cage environment (Mononen et al. 1995, 1996a, b) that mod- 


\section{AGRICULTURAL AND FOOD SCIENCE IN FINLAND}

\section{Mononen, J. et al. Effects of cage size and obstructed view on use of resting platforms}

ify foxes' behaviour in experimental and real cage environments and may thus confuse our understanding of what the animal really prefers and why. On the other hand some discrepancies between results from different studies may also be due to differences in experimental set-ups, e.g. in size of cages and size and type of platforms. For example, a nest box inside the cage reduces the free floor area of the cage; the foxes may then use the roof of the box, i.e. one type of platform, more than platforms that do not restrict the free floor area (Mononen et al. 1995).

In the present study, two hypotheses presented by Mononen et al. (1995) were tested on farmed silver foxes. According to 'the view hypothesis', more use is made of platforms in cages with an obstructed view from the cage floor, but according to 'the reduced space hypothesis' the platforms offer extra space which is used more in cages with restricted floor area. The size and height of the platforms were kept constant and all the experimental animals were exposed to all five types of experimental cage, i.e. they acted as their own controls.

\section{Material and methods}

The experiment was conducted at the Fur Animal Research Station of the University of Kuopio in Juankoski, eastern Finland. The experimental silver foxes were raised according to the normal Finnish commercial practice. They were given fresh feed once a day, and water was available ad libitum or was made available twice a day.

\section{Cages and platforms}

The experimental wire mesh cages were in a tworow shed. The cage floor was $50 \mathrm{~cm}$ above the level of the corridor floor of the shed and about $75 \mathrm{~cm}$ above the ground. In each cage there was a wooden resting platform $(45 \times 70 \mathrm{~cm})$. The plat- forms were hung $25 \mathrm{~cm}$ from the cage ceiling. Four platform types and two cage sizes were combined to provide five cage types (Figure 1):

A. The standard cage $(105 \times 115 \times 70 \mathrm{~cm}, \mathrm{Wx}-$ $\mathrm{LxH}$ ) with a box type platform. The fox could not go under the platform, and the view from the cage floor was obstructed.

B. The standard cage with a platform and walls below it obstructing the view. The fox could go under the platform but the view from beneath the platform was obstructed by hardboard walls attached to the cage wall.

C. The standard cage with a platform. The fox could go under the platform and had an unobstructed view from beneath the platform.

D. The standard cage with a platform without access under the platform. The fox could not go under the platform, as access was prevented by wire mesh walls, but the view from beneath the platform was not obstructed.

E. A big cage $(105 \times 240 \times 70 \mathrm{~cm}$, WxLxH) with a box type platform. The fox could not go under the platform and the view from beneath the platform was partly obstructed in that direction.

There were five cages of each type. The different types of cage were in series such that a cage with an unobstructed view (C and D) was always next to another cage with an unobstructed view, i.e. Type $\mathrm{C}$ cage, Type $\mathrm{D}$ cage, the half of the Type E cage without the platform or a cage without a platform with a non-experimental animal. Likewise a cage with an obstructed view (A or B) was always next to another cage with an obstructed view, i.e. Type A cage, Type B cage, the half of the Type E cage with the boxtype platform or a Type A cage with a non-experimental animal. Thus, in Type $C$ and $D$ cages the view was unobstructed for at least about one metre in both directions in the cage row and in Type A and B cages the view was always partly obstructed in both directions in the cage row. In Type E cages the view was partly obstructed in the direction of the box type platform and unobstructed in the other direction. Thus, in Type E cages an area was available, the half of the cage 


\section{AGRICULTURAL AND FOOD SCIENCE IN FINLAND}

Vol. 6 (1997): 183-191.

Cage A

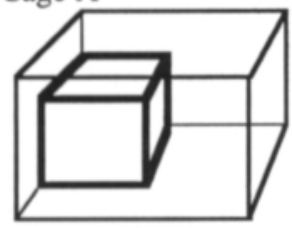

Cage C
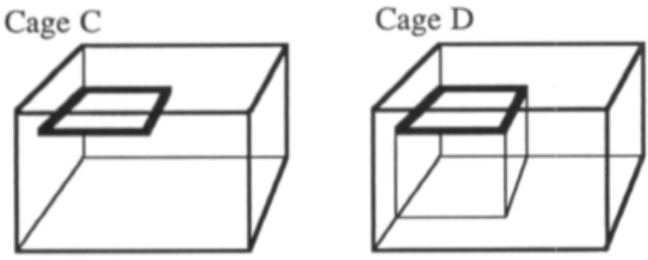

Cage E

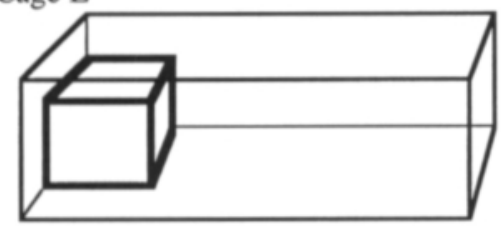

Fig. 1. Schematic drawings of the five cage types. See text for details.

without the nest box, from which the view was almost as good as from Type C and D cages, and substantially better than from Type A or B cages. Therefore, the Type E cage was classified as a cage with an unobstructed view. Both series of cages, with and without the obstructed view, were in two cage rows in the shed.

Hence, a fox (especially when lying) on the floor of a cage in which the platform obstructed the view, i.e. Type A and B cages, was severely hindered from seeing either the foxes in the neighbouring cages or anyone approaching its cage along the aisle of the shed. In these cages the platform structures also narrowed the sector in which the foxes could see the foxes in the other cage row of the shed and the area outside the shed. On the left side of the shed there was a 30$\mathrm{m}$-wide open area and beyond that farm buildings with plenty of human activity. On the right side there was a shed housing raccoon dogs ( $\mathrm{Nyc}$ tereutes procyonoides) at a distance of $5 \mathrm{~m}$. The view from the Type $\mathrm{C}$ and Type $\mathrm{D}$ cages and from the half of the Type E cage without the nest box was minimally obstructed in all directions.

\section{Animals, procedure and observations}

The experimental silver foxes (15 females, 10 males) were born in May 1994 and weaned at about 8 weeks. Thereafter they were housed singly in standard fox cages $(105 \times 115 \times 70 \mathrm{~cm}$, $\mathrm{WxLxH}$ ) without any platforms or nest boxes. The foxes were from 11 litters. Five experimental groups were formed. Each group was composed of three females and two males. The coefficient of relatedness of the foxes within each group was less than 0.25 .

The experiment comprised five 2-week periods. Each individual fox was housed alone in each type of cage for 2 weeks. The different cage types were introduced to the different groups in the following order: Group 1, ACEDB; Group 2, BEDCA; Group 3, CDABE; Group 4, DABEC and Group 5, EBCAD. On the first day of Period 1 (5th September 1994) two or three foxes from each group were allocated to the left cage row and two or three to the right cage row. Owing to the arrangement of the cages the individuals in each group were thus distributed along longitudinal axis of the shed. On the first day of Periods 2-5 each fox was transferred to a new cage. To reduce any effects due to cage location, each individual was exposed to both the left and right cage rows and to the front, middle and rear sections of the shed during the experiment. The platforms remained fairly clean, but due to occasional defecating and urinating on the platforms they were cleaned by scraping, if necessary, on the first day of each period before a new animal was transferred to the cage.

The behaviour of each animal was video recorded for 24 hours during the second week of each period. The video system is described in Mononen et al. (1996a). During dark hours dim red lights (Philips E27ES, $60 \mathrm{~W}$ ) were used. Otherwise the lighting was natural. Ambient temperature was recorded at 0800 each morning.

The behaviour of the foxes was analysed from 


\section{AGRICULTURAL AND FOOD SCIENCE IN FINLAND}

Mononen, J. et al. Effects of cage size and obstructed view on use of resting platforms

Table 1. Categories of recorded behavioural states and their combinations, i.e. the behavioural variables. Lying in a curled or stretched-out posture was recorded as resting and all other behaviour as active behaviour.

\begin{tabular}{|c|c|}
\hline Category & Behaviour \\
\hline AP & Active on the platform \\
\hline RP & $\begin{array}{l}\text { Resting awake or asleep on the } \\
\text { platform }\end{array}$ \\
\hline $\mathrm{AF}$ & Active on the wire mesh floor \\
\hline RF & $\begin{array}{l}\text { Resting awake or asleep on the wire } \\
\text { mesh floor }\end{array}$ \\
\hline $\mathrm{TA}=\mathrm{AP}+\mathrm{AF}$ & Total activity \\
\hline $\mathrm{TP}=\mathrm{AP}+\mathrm{RP}$ & Total time on the platform \\
\hline $\mathrm{PAP}=\mathrm{AP} /(\mathrm{AP}+\mathrm{AF})$ & $\begin{array}{l}\text { Proportion of active time on the } \\
\text { platform }\end{array}$ \\
\hline$P R P=R P /(R P+R F)$ & $\begin{array}{l}\text { Proportion of resting time on the } \\
\text { platform }\end{array}$ \\
\hline
\end{tabular}

the video tapes using an instantaneous sampling method (Martin and Bateson 1993) with a 5-min sampling interval. The behavioural categories used are presented in Table 1.

\section{Statistics and presentation of data}

The behavioural results were calculated as percentages of observations and are hereafter called 'percentages of time' or 'percentages of active/ resting time'. The results are presented in the text as mean \pm standard deviation, but in figures only as means. The effects of cage types (i.e. cage size and platform type), advancing time (i.e. experimental period) and sex on platforms use were analysed by using the variables TP (proportion of total time on platform), PAP (proportion of total active time on platform) and PRP (proportion of total resting time on platform) (Table 1). The variables PAP and PRP were used instead of AP (active time on platform) and RP (resting time on platform) because the daily percentage of active time varied between the periods and also tended to vary between the sexes.

Many behavioural variables were neither normally distributed nor transformable. Therefore, non-parametric statistics were used. Due to the lack of suitable nonparametric methods the interactive effects of the independent variables (cage type, sex and advancing time) on behaviour could not be directly analysed but had to be deduced from separate analyses. The number of animals in each analysis varied, because some data were lost due to dysfunction of the video recorder during Period 2.

The view hypothesis predicts that the platforms are used more in cages with an obstructed view from the cage floor. Thus, the platforms should be used more in Type A and B cages than in Type C, D or E cages. To allow for the possible effects of cage size (big cage $v s$ standard cage) the comparison $\mathrm{AB}$ vs $\mathrm{CD}$ was included. According to the reduced space hypothesis the platforms offer extra space which is used more in cages where the floor area is restricted. Thus, the rate of platform use in different cage types should be in the order: $A=D>B=C>E$. To test these two hypotheses, the behaviour of each individual was pooled by calculating the mean for each behavioural state for two or more cage types as required by each hypothesis. For example, to compare platform use in the cages with an obstructed view $(\mathrm{AB})$ with that in cages with an unobstructed view (CDE), the mean platform use in cages $\mathrm{AB}$ was calculated for each individual and compared with the mean use in cages CDE calculated similarily. The Wilcoxon matchedpairs signed-ranks test and the Page test for ordered alternatives were used to compare two and three pools, respectively (Siegel and Castellan 1988).

The effect of advancing time (i.e. the differences between the periods) was analysed by comparing the five periods with Friedman two-way ANOVA. The effect of sex was studied by pooling the data from all periods within each individual and comparing the behaviour between the sexes with the Mann-Whitney U-test (Siegel and Castellan 1988).

The interactions between the cage types and advancing time were studied by pooling the animal groups within each period according to the two hypotheses and comparing the groups within each period with the Mann-Whitney U-test 
Vol. 6 (1997): 183-191.

Fig. 2. The behaviour of silver foxes $(n=18)$ during the five periods. The differences between the periods are significant for all four variables ( $\mathrm{p}<0.05$, Friedman two-way ANOVA). The dates are the days of the 24-hour video recordings during the second week of each period. Below the dates are the temperature ranges $\left({ }^{\circ} \mathrm{C}\right)$ of morning temperatures (at 0800) and mean day lengths (h.min) for the video recording days of each period.

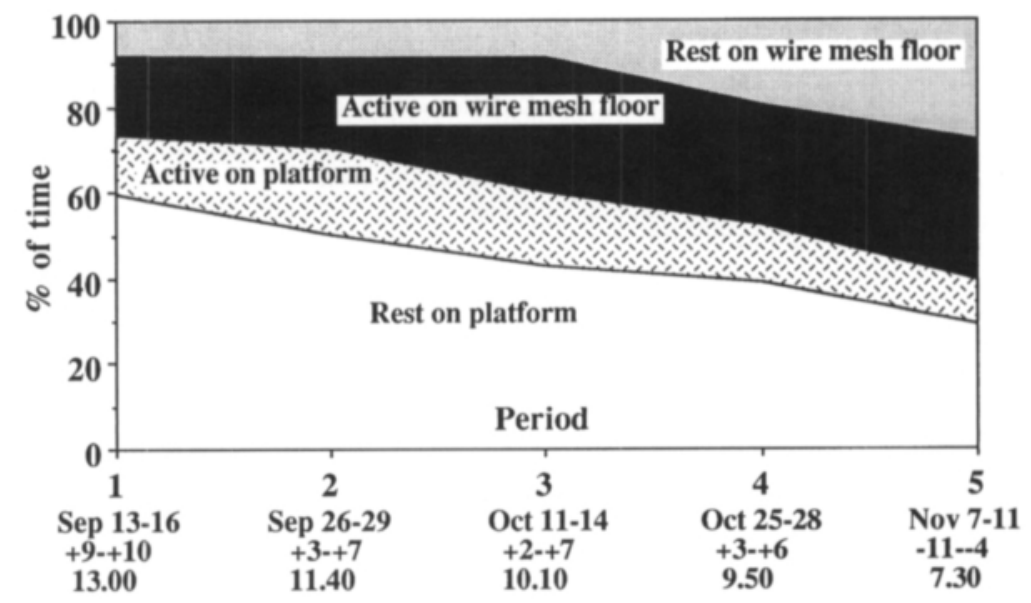

(two pools) or the Jonkheere test for ordered alternatives (three pools) (Siegel and Castellan 1988).

The interactions of sex with cage type and advancing time were studied by analysing the effects of cage type and advancing time for both sexes separately. The results of these analyses were compatible with those of the analyses with both sexes. Thus, for briefness, only the results of the sex-pooled data are presented.

In the case of the differences between two pools of cage types, one-tailed probabilities were used, since the a priori hypotheses determined the order of the pools. Note that the Page test and Jonkheere test are also considered to be onetailed tests. Otherwise two-tailed probabilities were used (Siegel and Castellan 1988).

\section{Results}

The silver foxes were active $41 \pm 3 \%$ of their daily time (pooled result for five periods). The percentage of daily activity varied in the course of the experiment, being $33 \pm 5 \%, 41 \pm 4 \%$,
$49 \pm 4 \%, 43 \pm 5 \%$ and $44 \pm 6 \%$ of time $(\mathrm{N}=18$, $\mathrm{P}<0.001$, Friedman two-way ANOVA) for Periods 1-5, respectively. Males were active $40 \pm 2 \%$ and females $43 \pm 3 \%$ of daily time ( $\mathrm{n}=10$ and 8 , respectively; $p=0.076$, Mann-Whitney U-test).

The foxes spent $59 \pm 13 \%$ of their daily time on the platforms. The platforms were used more for resting $(44 \pm 10 \%)$ than for active behaviour ( $15 \pm 4 \%$ of daily time, $N=18, p<0.001$, Wilcoxon matched-pairs signed-ranks test), representing $75 \pm 17 \%$ and $37 \pm 9 \%$ of the total daily resting and active time, respectively. Daily platform use declined steadily in the course of the experiment (Figure 2).

The males spent more time on the platforms than did the females: $64 \pm 9 \%$ and $53 \pm 15 \%$ of their daily time, respectively $(\mathrm{p}<0.05$, MannWhitney U-test). This difference was due to the differences in platform use for resting (PRP: $82 \pm 9 \%$ vs $65 \pm 20 \%, \mathrm{p}<0.05$ ) rather than for active behaviour (PAP: $38 \pm 9$ vs $35 \pm 9 \%$, $\mathrm{p}=0.42$ ).

In the period-pooled data the percentage of active time spent on the platform was greater in cages with a restricted view $(\mathrm{AB})$ than in those with an open view (CDE) (Table 2). A parallel tendency was noted in use of the platform for 


\section{AGRICULTURAL AND FOOD SCIENCE IN FINLAND}

Mononen, J. et al. Effects of cage size and obstructed view on use of resting platforms

Table 2. Percentage of total daily time (TP), percentage of total daily active time (PAP) and percentage of total daily resting time (PRP) spent on resting platforms by juvenile silver foxes. The five cage types (A, B, $\mathrm{C}, \mathrm{D}, \mathrm{E})$ were combined into appropriate pools to test the restricted view hypothesis and the reduced space hypothesis (see text for details).

\begin{tabular}{|c|c|c|c|c|c|}
\hline Variable & Cages vs & Cages & Cage & $\mathrm{N}$ & $\mathrm{p}$ \\
\hline \multicolumn{6}{|c|}{ Restricted view hypothesis } \\
\hline & $\mathrm{AB}$ & $\mathrm{CD}$ & & & \\
\hline TP & $64 \pm 12$ & $58 \pm 22$ & & 20 & 0.29 \\
\hline PAP & $41 \pm 9$ & $38 \pm 13$ & & 20 & 0.17 \\
\hline \multirow[t]{2}{*}{ PRP } & $80 \pm 16$ & $71 \pm 30$ & & 20 & 0.18 \\
\hline & $\mathrm{AB}$ & $\mathrm{CDE}$ & & & \\
\hline TP & $64 \pm 12$ & $56 \pm 19$ & & 18 & 0.079 \\
\hline PAP & $40 \pm 11$ & $33 \pm 12$ & & 18 & 0.039 \\
\hline PRP & $81 \pm 16$ & $70 \pm 24$ & & 18 & 0.061 \\
\hline \multicolumn{6}{|c|}{ Reduced space hypothesis } \\
\hline & $\mathrm{AD}$ & $\mathrm{BC}$ & E & & \\
\hline TP & $61 \pm 21$ & $60 \pm 14$ & $54 \pm 20$ & 18 & 0.31 \\
\hline PAP & $39 \pm 13$ & $37 \pm 10$ & $30 \pm 12$ & 18 & 0.091 \\
\hline PRP & $75 \pm 26$ & $75 \pm 20$ & $72 \pm 25$ & 18 & 0.43 \\
\hline
\end{tabular}

p: Wilcoxon matched pairs signed ranks test or Jonkheere test for ordered alternatives

resting and total use. Such differences were not seen, however, in the comparisons without the big cage ( $\mathrm{AB} v s \mathrm{CD})$. Furthermore, the extent of platform use for activity was lower in the big cage (E) than in the smaller cages with the unobstructed view (CD). Thus, the difference in use of the platform for activity between the cages with an obstructed view and those with an unobstructed view in the comparison with the big cage ( $\mathrm{AB}$ vs $\mathrm{CDE}$ ) may actually be due to a combined effect of view and size. However, the platforms were clearly used less in the cages with an unobstructed view (CDE) than in those with an obstructed view (AB) in Periods 4 and 5 (Figure 3: top). In these periods the comparison without the big cage ( $\mathrm{CD}$ vs $\mathrm{AB}$ ) yielded similar results: $p$ values for the variables PRP, PAP and TP were $0.016,0.056$ and 0.056 in Period 4 and $0.0076,0.021$ and 0.014 in Period 5, respectively.

Only the time the foxes were active on the platform tended to depend on the free floor area of the cage in the period pooled data (Table 2). This effect reached statistically significant level during Periods 1 and 3 (Figure 3: bottom).

\section{Discussion}

The total amount of platform use and the rate of decline in use during autumn in the present study are in accordance with the use of platforms or nest box roofs of corresponding size and height by juvenile silver foxes reported earlier (Korhonen and Niemelä 1995a, Mononen et al. 1995, 1996c). Here, the male silver foxes used the platforms more than did the females. Korhonen and Niemelä reported that both juvenile (1995a) and adult (1996) silver fox females used platforms more than males. However, in the above studies of juvenile foxes, both the observation method, that is, 56 scan samples per month recorded during working days, and the number of animals in one cage (male and female), differed from ours.

Seasonal changes in platform use are similar in silver foxes and blue foxes. Several reasons have been suggested for these changes (e.g. Korhonen and Niemelä 1996, Korhonen et al. 1996). First, the platforms might be used less in the winter because the foxes are then heavier and perhaps too clumsy to jump up onto the platform 
Vol. 6 (1997): 183-191.
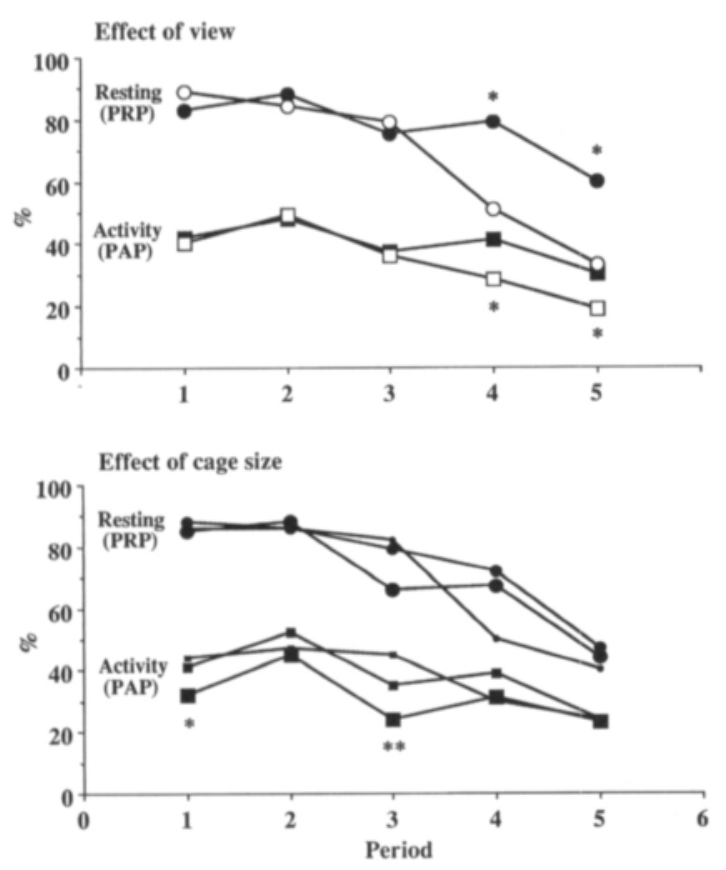

Fig. 3. The effects of obstructed view and cage size on platform use ( $\%$ of active/resting time, mean) by silver foxes. The asterisks above or below a pair or group of lines (PRP or PAP) indicate a difference between the cage types $\left({ }^{*} \mathrm{p}<0.05,{ }^{* *} \mathrm{p}<0.01\right.$, Mann-Whitney U-test and Jonkheere test for ordered alternatives for top figure and bottom figure, respectively) within that variable in that period. Top: Closed symbols $=\mathrm{AB}$ cages with obstructed view, open symbols $=$ CDE cages with unobstructed view. $\mathrm{N}=10$ and 15 , respectively, except 10 and 9 in Period 2. Bottom: small symbol=AD cages $\left(1.2 \mathrm{~m}^{2}\right)$ with platform that reduces free floor area, medium size symbol=BC cages $\left(1.2 \mathrm{~m}^{2}\right)$, big symbol=E big $\left(2.4 \mathrm{~m}^{2}\right)$ cages. $\mathrm{N}=10,10$ and 5 , respectively, except 8,7 and 3 in Period 2.

(Korhonen and Niemelä 1996). However, there were no differences in platform use in October between blue foxes with and without melatonin treatment, although the melatonin-treated animals were $2.4 \mathrm{~kg}(31 \%)$ heavier than the control animals (Korhonen et al. 1996). Second, use may vary for thermoregulatory reasons. Under practical farming conditions solid platforms get icy in winter, and an animal lying on an icy wooden platform loses more heat than one lying on the wire mesh floor of the cage (Korhonen 1987).
Moreover, many platform types may be so narrow that they prevent the foxes from adopting the curled posture required for maximum winter fur insulation. On the other hand, the platforms may offer a shady place for resting in the summer (Korhonen and Niemelä 1996). We found here, however, that use of the platforms decreased from period to period, even though the temperature was more or less stable from Period 2 to Period 4 and was below zero only in Period 5 (Figure 2). Furthermore, the platforms were wide enough for the foxes to adopt the curled posture. Third, if the platforms act as observation places, it is feasible that daily use would decline with decreasing day length, since the foxes would have no use for an observation place in the dark. In the present study, platform use did indeed decline with shortening day length (Figure 2). However, we cannot be sure whether or not this relation is causal, since day length is correlated with many other factors (e.g. ambient temperature, and the age, weight and fur thickness of the foxes). Furthermore, more detailed analysis revealed that platform use declined from period to period during working day, too, i.e. during light hours when there is plenty of human and animal activity to be observed on the farm.

The traditional two-row fox sheds with wiremesh cages without any furnishings and raised $60-100 \mathrm{~cm}$ above the ground (Commission of the European Communities 1990) provide farmed foxes with an open view in all directions. Thus, the fact that foxes prefer to spend their time on a raised wooden platform as noted here and in earlier studies (e.g. Korhonen and Niemelä 1995a, Korhonen et al. 1996) suggests that foxes prefer a solid surface to a wire mesh floor. However, blue foxes use wooden and wire-mesh platforms in equal frequencies in the autumn (Korhonen and Niemelä 1995b), whereas in the winter, they use the wire mesh platforms more than wooden ones (Korhonen et al. 1996). There is indirect evidence that silver foxes do not prefer solid surfaces to wire-mesh surfaces (Jeppesen and Pedersen 1990, Korhonen and Niemelä 1994), although very young cubs may be exceptions to 


\section{Mononen, J. et al. Effects of cage size and obstructed view on use of resting platforms}

this rule (Skovgaard et al. 1995). Thus, it seems that being at a higher elevation matters to juvenile foxes in the autumn more than being on a solid surface. And the higher they are in the cage, the better the view they usually have.

We found here that the view seemed to affect platform use more than did cage size. This conclusion is compatible with that of Mononen et al. (1996a). However, the effects of view and cage size could not be detected systematically throughout the study. Furthermore, there may have been a combined effect of cage size and obstructed view.

The effect of the obstructed view was observed only during Periods 4 and 5, when it was indeed strong. Use of resting platforms by farmed foxes is affected by several factors (e.g. Mononen et al. 1996c). We may assume, that the factors that make the foxes use their platforms less either lessen the benefits or increase the costs of using the platforms. The silver foxes we studied may have regarded use of the platforms more beneficial in the cages with an obstructed view than in those with an open view in late autumn. This supports our earlier observations that farmed silver foxes, to some extent, avoid cages, cage sections or furnishings with an obstructed view (Mononen et al. 1993, 1995, 1996b).

The effect of cage size was detectable only during Periods 1 and 3 and only when the foxes were active while on the platforms. The effect of cage size may simply indicate that the platform acts more as extra space in the cages with a smaller free floor area than in the cages with a larger floor area.

\section{Conclusions}

Juvenile farmed silver foxes spent a substantial proportion of their daily time on wooden platforms in the autumn. Use declined towards the winter, but less in cages with an obstructed view than in cages with an open view. In early autumn, use of the platforms for activity decreased to some extent in larger cages. The present results support earlier findings that one probable function of the platforms is to offer the foxes an observation and resting place with a good view in all directions.

Acknowledgements. We thank Matti Tengvall for taking care of the animals and Harri Nurmela, Juhani Sepponen and Asko Vähärautio for their technical assistance. We also thank Dr Julie Morrow-Tesch for helping us with the English. The study was financed by the Research Council for Agriculture and Forestry of Academy of Finland, Finnish Fur Breeders' Association and Finnish Fur Sales Co Ltd.

\section{References}

Commission of the European Communities 1990. Contract no. 3814/12, Study into Legal, Technical and Animal Welfare Aspects of Fur Farming. C \& T Services, Sussex. $111 \mathrm{p}$.

European Convention 1991. European Convention for the Protection of Animals Kept for Farming Purposes, Strasbourg 1976, ETS 87. Recommendation Concerning Fur Animals, 25 June 1991. 19 p.

Jeppesen, L. L. \& Pedersen, V. 1990. Improvement of management routines and cage systems in fox production. Scientifur 14: 237-242.

Korhonen, H. 1987. Significance of sleeping plate as a thermal protection for farmed raccoon dogs (Nyc- tereutes procyonoides). Comparative Biochemistry and Physiology 87A: 631-633.

-, Ketoja, E. \& Niemelä, P. 1995. Comparison of daytime use between platform types, materials, ceilings and experiences in juvenile blue foxes (Alopex lagopus). Applied Animal Behaviour Science 45: 125-138.

- \& Niemelă, P. 1994. Preferences of silver and blue foxes for farm cage and pen. Nordiske Jordbrugsforskeres Forening, Seminar $n r .253$, 28th-30th September 1994, Skörping, Denmark. 15 p.

- \& Niemelä, P. 1995a. Platform use by juvenile and adult silver foxes (Vulpes vulpes). Scientifur 19: 179-187.

- \& Niemelä, P. 1995b. Comparison of production results 
Vol. 6 (1997): 183-191.

between blue foxes housed with and without platforms. Agricultural Science in Finland 4: 351-361.

- \& Niemelä, P. 1996. Seasonal changes in platform use by adult farmbred silver foxes (Vulpes vulpes). Agricultural and Food Science in Finland 5: 3-15.

-, Niemelä, P. \& Tuuri, H. 1996. Seasonal changes in platform use by farmed blue foxes (Alopex lagopus). Applied Animal Behaviour Science 48: 99-114.

Martin, P. \& Bateson, P. 1993. Measuring behaviour, An introductory guide, 2nd ed. Cambridge University Press, Cambridge. 222 p.

Mononen, J., Harri, M. \& Rekilä, T. 1996a. Comparison of preferences of farmed silver and blue foxes for cages with and without a nest box. Acta Agriculturæ Scandinavica, Section A, Animal Science 46: 117124.

-, Harri, M. \& Rekilä, T. 1996b. Farmed foxes prefer a cage with an unobstructed view. Scandinavian Journal of Laboratory Animal Science 23: 43-48.

-, Harri, M., Rekilä, T., Korhonen, H. \& Niemelä, P. 1995. Use of nest boxes by young farmed silver foxes ( Vul- pes vulpes) in autumn. Applied Animal Behaviour Science 43: 213-221.

-, Harri, M., Rouvinen, K. \& Niemelä, P. 1993. The use of resting platforms by young silver foxes (Vulpes vulpes). Applied Animal Behaviour Science 38: 301-310.

-, Korhonen, H., \& Harri, M. 1996c. Resting platforms for farmed foxes - a short review. In: Frint A. \& Brzozowski. M. (Eds). Applied Science Reports 29. Progress in fur animal science. Proceedings from the VIth International Scientific Congress in Fur Animal Production, August 21-23, 1996, Warsaw, Poland. Polish Society of Animal Production, Warsaw. p. 6569 .

Siegel, S. \& Castellan, N. J. 1988. Nonparametric Statistics for the Behavioural Sciences, 2nd ed. McGrawHill, New York. 399 p.

Skovgaard, K., Pedersen, V. \& Jeppesen, L. L. 1995. Præference for forskellige bundtyper hos blåræve. Nordiska Jordbruksforskares Förening, Seminar October 4th-6th,1995, Gothenburg, Sweden, 5 p. (In Danish)

\title{
SELOSTUS
}

\section{Häkin koon ja häkissä olevien näköesteiden vaikutus tarhattujen hopeakettujen makuuhyllyn käyttöön}

\author{
Jaakko Mononen, Mikko Harri ja Leena Ahola \\ Kuopion yliopisto
}

Häkkikoon ja häkissä olevien näköesteiden vaikutusta nuorten hopeakettujen puisten makuuhyllyjen käyttöön tutkittiin kymmenen viikkoa kestäneessä kokeessa. Kokeessa vertailtiin viittä erilaista häkkityyppiä. Häkkien koko ja näkyvyys häkistä vaihtelivat. Jokainen eläin vietti kaksi viikkoa kunkin tyyppisessä häkissä. Eläinten käyttäytymistä videoitiin 24 tuntia yhtäjaksoisesti jokaisen kahden viikon jakson jälkimmäisellä viikolla.

Ketut viettivät $59 \pm 13 \%$ päivittäisestä ajastaan hyllyillä. Käyttö väheni syksyn kuluessa syyskuun $72 \pm 13 \%$ :sta marraskuun $35 \pm 21 \%$ :iin. Urokset käyttivät hyllyjä hieman enemmän kuin naaraat. Lokakuun loppupuolella ja marraskuun alkupuolella ketut käyttivät hyllyjä enemmän sekä aktiiviseen käyttäytymiseen että lepoon häkeissä, joista näkyvyys häkin lattialta oli osittain estetty verrattuna häkkeihin, joista oli avoin näkyvyys. Elokuun puolivälissä ja syyskuun puolivälissä vapaan lattiapinta-alan suuruus vaikutti hyllyjen käyttöön: mitä suurempi vapaa lattiapinta-ala, sitä pienemmän osuuden aktiivisesta ajastaan eläimet viettivät hyllyllä. Hyllyt toimivat mitä ilmeisimmin tarkkailu- tai lepopaikkoina, joista on esteetön näkyvyys ympäristöön. 